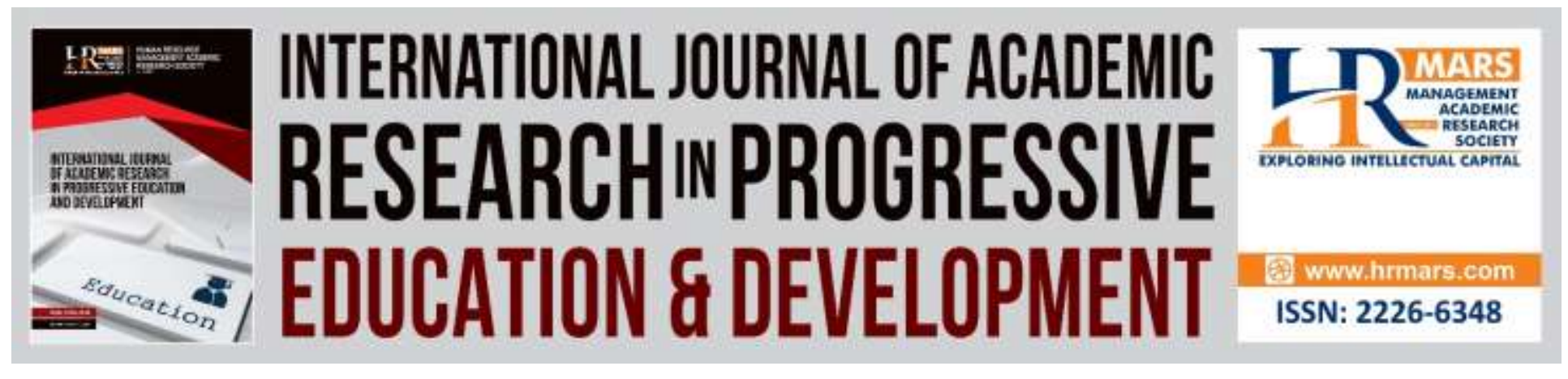

\title{
Learning Strategy and Higher Order Thinking Skills of Students in Accounting Studies: Correlation and Regression Analysis
}

Nor Sa'adah Jamaluddin, Suhaida Abdul Kadir, Arnida Abdullah \& Siti Noormi Alias

To Link this Article: http://dx.doi.org/10.6007/IJARPED/v8-i4/6670

DOI:10.6007/IJARPED/v8-i4/6670

Received: 12 October 2019, Revised: 28 October 2019, Accepted: 16 November 2019

Published Online: 30 November 2019

In-Text Citation: (Jamaluddin, Kadir, Abdullah, \& Alias, 2019)

To Cite this Article: Jamaluddin, N. S., Kadir, S. A., Abdullah, A., \& Alias, S. N. (2019). Learning Strategy and Higher Order Thinking Skills of Students in Accounting Studies: Correlation and Regression Analysis.

International Journal of Academic Research in Progressive Education and Development, 8(4), 616-626.

Copyright: (C) 2019 The Author(s)

Published by Human Resource Management Academic Research Society (www.hrmars.com)

This article is published under the Creative Commons Attribution (CC BY 4.0) license. Anyone may reproduce, distribute, translate and create derivative works of this article (for both commercial and non-commercial purposes), subject to full attribution to the original publication and authors. The full terms of this license may be seen

at: http://creativecommons.org/licences/by/4.0/legalcode

\section{Vol. 8(4) 2019, Pg. 616 - 626}

http://hrmars.com/index.php/pages/detail/IJARPED

JOURNAL HOMEPAGE

Full Terms \& Conditions of access and use can be found at http://hrmars.com/index.php/pages/detail/publication-ethics 


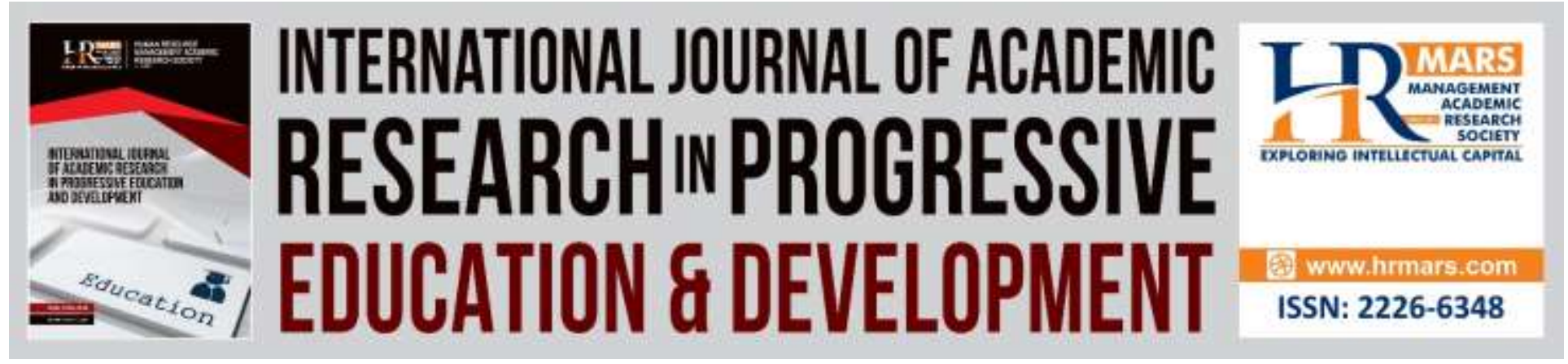

\title{
Learning Strategy and Higher Order Thinking Skills of Students in Accounting Studies: Correlation and Regression Analysis
}

\section{Nor Sa'adah Jamaluddin, Suhaida Abdul Kadir, Arnida Abdullah \& Siti Noormi Alias}

Faculty of Educational Studies, Universiti Putra Malaysia (UPM), 43400 Serdang, Selangor, Malaysia

\begin{abstract}
The mastery of Higher Order Thinking Skills (HOTS) among students is a reflection appropriate learning strategies that students have applied. Therefore, the choice of learning strategies that are relevant to the subjects being studied is seen as contributing to the successful in mastering of HOTS among students. However, does this response also occur in the selection of learning strategies and HOTS's mastery in Accounting Studies? Hence, this research was conducted with the aim of examining the relationship between HOTS and learning strategies in Accounting Studies. This study is conducted by employing correlation research method on 340 students studying Accounting Studies in Peninsular Malaysia participated in this research through completing a self-administered questionnaire which included the Learning and Study Strategies Inventory (LASSI) and Higher Order Thinking Skills Test. Applying skills, analytical skills, evaluative skills, and creative skills are among the four elements of HOTS tested. The analysis showed that positive significant relationship $(r=0.194)$ exists between the two variables and the regression equation is an average grade point $=46.442+4.349$ Learning Strategies. Thus, through correlation and regression analysis, significant regression model between HOTS and Learning Strategies were found.
\end{abstract}

Keywords: Learning Strategies, Higher Order Thinking Skills, Accounting Studies, Correlation and Regression Analysis

\section{Introduction}

Understanding and identifying students' learning strategies (Afsaneh, 2017; Jamie, Mark, Steven, \& Tyler, 2014; Sanoff, 2000) in a given subject also helps to provide a comprehensive overview of factors that contribute to higher levels of HOTS among students (Sanip \& Ahmad, 2014). When a student recognizes the right and appropriate learning strategies for themselves, 
the learning process becomes easier (Lopez, Ibanez, \& Racines, 2017) and at the same time maximizes students' potential for HOTS (Sanip \& Ahmad, 2014).

Research on secondary school students' learning strategies has not only gained attention over the past two decades (Carol, David, \& Peter, 2011l; Ibrahim, 2010) but has continued to focus on transforming national education through the Malaysian Education Development Plan (MEDP) (2013-2025). Learning strategies are defined as thoughts or behaviours that help to enhance the translation process, affect the motivation and affective levels, and outcomes of a student's learning (Weinstein, Zimmermann, \& Palmer, 1988; Weinstein \& Mayer, 1986). Learning strategies are also defined as general planning in an action plan for carrying out learning tasks (Dumford, Cogswell, \& Miller, 2016a) that focuses to attention and effort, processes information in depth and monitors comprehension (Baskin, Iscan, Karagoz, \& Birol, 2017) to achieve a goal.

Based on the learning strategies definitions presented, the findings of previous studies have also shown that most students with learning disabilities include applying higher level thinking skills not because of their level of intellect, but because of their lack of metacognitive, cognitive, and affective learning strategies (Hassan, 2017 ; Wijnen, Loyens, Smeets, Kroeze, \& Van, 2017; Kikas \& Jogi, 2016; Bathuma \& Kalaimakal, 2014). This is evidenced by previous studies explaining that the use of effective learning strategies is one of the major factors contributing to student success (Dansereau, 1985; Weinstein \& Mayer, 1986).

Metacognitive, cognitive, and affective strategies are among the learning strategies that are frequently noted in a variety of previous studies. This is because all of three learning strategies involve a holistic learning element in measuring the development of achievement and 21st century skills within each student (Wijnen et al., 2017; Curriculum Development Division, 2016; Jeffrey, 2014). Understanding student-centered learning strategies can help teachers in their teaching sessions at school (Dumford, Cogswell, \& Miller, 2016b). This is because, by informing the learning strategies used by students in their learning, it will be able to guide teachers in selecting the right teaching methods or strategies to be apply for ensure learning and teaching sessions achieve their goals (Hassan, 2017).

This finding is supported by Wijnen et al., (2017) who found that aspects of learning strategies used by students contribute to student achievement in metacognitive, cognitive, and affective aspects. However, studies by Sanip and Ahmad (2014) and Mansuri (2002) found no significant relationship between student learning strategies and student achievement. Therefore, the discrepancies in the findings encourage the researcher to pursue research on the extent to which the learning strategies used by students impact learning outcomes that include the application of students' HOTS for the purpose of generating new insights.

Higher Order thinking skills (HOTS) are defined as the ability to use the potential of the mind to overcome new challenges because HOTS challenge individuals to interpret, analyze or manipulate information (Yee, Yunos, Othman, Hassan, Tee, \& Mohamad, 2015; Mohamed, 2006; 
Ea, Chang \& Tan, 2005; Onosko \& Newmann, 1994). The level of thinking in the Bloom's Taxonomy revises Anderson's defined HOTS as a level of thinking referring to the skills of applying, analyzing, evaluating, and creating. Hence, in this study, researchers measured the level of Accounting Studies based on the stipulations in the High School Curriculum Standard (HSCS) using the Revised Bloom's Taxonomy 2001 (Anderson \& Krathwohl's, 2001); thinking skills, analytical skills, assessment skills, and creative skills.

Operationally, learning strategies are defined as a thinking and behaviour processes used by students in Accounting Studies which includes components of metacognitive strategies (time management), cognitive strategy (concentration), and affective strategies (attitude, motivation, and anxiety). Therefore, some of the questions raised are: is there a relationship between learning strategies and student HOTS performance in Accounting Studies? How strong is the relationship between student learning strategies and HOTS achievement? Is the relationship linear? To answer this question, it is necessary to investigate the relationship between learning strategies and HOTS in Accounting Studies.

\section{Method}

This study used a correlation study design to examine the relationship between two or more variables. Researchers examined the strengths and correlations between HOTS and learning strategy variables without manipulating any of these variables. Thus, through the use of statistical correlation test the aim of examining the relationship between variables can contribute to a more comprehensive study.

The population of students in Accounting Studies is 39,695 and the selection of sample was 340 of students from Accounting Studies in Peninsular Malaysia. The sample was selected based on the random and proportionate sampling. This study used a set of questionnaire that was adapted from the Learning and Study Strategies Inventory (LASSI) and a set of higher order thinking skills test on Accounting Studies as the main instruments. Researcher have obtained the permission from the original authors via email to administer the questionnaire and the test. The instrument was translated to Malay Language and the reliability coefficient for the adapted instrument was 0.95 . There were 23 items that measure the dimension of learning strategies. Likert type scale scores were used for LASSI, ranged from strongly disagree to strongly agree. While, higher order thinking skills test was a regular and formal test in school, which had a total possible points of 100 .

Learning strategies and HOTS are two variables chosen by the researchers. Whereas, learning strategy are categorized as predictor variables HOTS are categorized as criterion variables. Therefore, for the purpose of this study the learning strategies are predictor variables that predicts students' level of HOTS's achievement in Accounting Studies. Performance appraisal of HOTS's test as stated in Table 1. 
INTERNATIONAL JOURNAL OF ACADEMIC RESEARCH IN PROGRESSIVE EDUCATION AND DEVELOPMENT

Vol. 8, No. 4, 2019, E-ISSN: 2226-6348 @ 2019 HRMARS

Table 1. Interpretation of Higher Order Thinking Skills Achievement

\begin{tabular}{ccc}
\hline Marks & Grade & Result \\
\hline $90-100$ & A+ & \\
$80-89$ & E & \\
$70-79$ & A- & \\
$65-69$ & B+ & Goodlent \\
$60-64$ & B & \\
$55-59$ & C & Pass \\
$50-54$ & C & \\
\hline $45-49$ & D & Fail \\
\hline $40-44$ & E & G
\end{tabular}

Malaysian Examination Board (2016)

The process of data analysis is done once all the data related to the study is completed. The use of correlation and regression statistics tests was used in this study to evaluate the strength of linear relationships and to estimate relationships between variables. Therefore, the use of regression and correlation analysis for the purpose of this study was to evaluate the relationship between students' HOTS's achievement and learning strategies applied by students in Accounting Studies. Details of the relationships between variables are shown in Table 2.

Table 2. Interpretation of Relationship between the Variables Using Coefficient Correlation

\begin{tabular}{cl}
\hline \multicolumn{1}{c}{ Coefficient } & Relationship \\
\hline 0.00 & No Correlation \\
$0.01-0.25$ & Weak Correlation \\
$0.26-0.50$ & Sufficient Correlation \\
$0.51-0.75$ & Strong Correlation \\
$0.76-0.99$ & Very Strong Correlation \\
1 & Perfect Correlation \\
\hline & Sarwono, 2009
\end{tabular}

\section{Results and Discussion \\ Descriptive Statistic}

Descriptive statistics are used by researchers for the purpose of presenting research findings in the form of figures and graphs that involve a big data. A simplified summary of data resulting from the use of descriptive statistics for the variables of learning strategies and HOTS is shown in Table 3. 
Vol. 8, No. 4, 2019, E-ISSN: 2226-6348 @ 2019 HRMARS

Table 3. Descriptive Statistic for Learning Strategies and HOTS

\begin{tabular}{cccccc}
\hline Variable & $\mathrm{N}$ & Minimum & Maximum & Mean & $\begin{array}{c}\text { Std. } \\
\text { Deviation }\end{array}$ \\
\hline $\begin{array}{c}\text { Learning } \\
\text { Strategies }\end{array}$ & 314 & 1.09 & 5.00 & 3.87 & 0.57 \\
\hline HOTS & 314 & 35.0 & 92.0 & 63.27 & 12.79 \\
\hline
\end{tabular}

According to Table 3, the minimum and maximum values of predictor variables (learning strategies) were 1.09 and 5.00 with a standard deviation of 0.57 . Whereas, the minimum and maximum values of the criterion variables (HOTS) were 35.0 and 92.0 with the standard deviation values of 12.79. Based on the large standard deviation values shown by the HOTS variables, this finding illustrates that the values in the data set are spread over a wide range around the mean values of the data sets. Whereas, the small standard deviation values shown by the Learning Strategies variable give the impression that the values in the data set are dispersed in a relatively small range around the mean values of the data sets. However, the state of the data dispersed in the range around the mean value explains that a good degree of variability exists in both variables, thus allowing for the implementation of correlation tests and regression to be continued.

Next, descriptive analysis of information on the data distribution is not provided. Therefore, the process of testing the normalization of the data is done using visual inspection method on the graph of Normal probability plot (Q-Q plot) (Gupta, 2007) as shown in Figure 1.

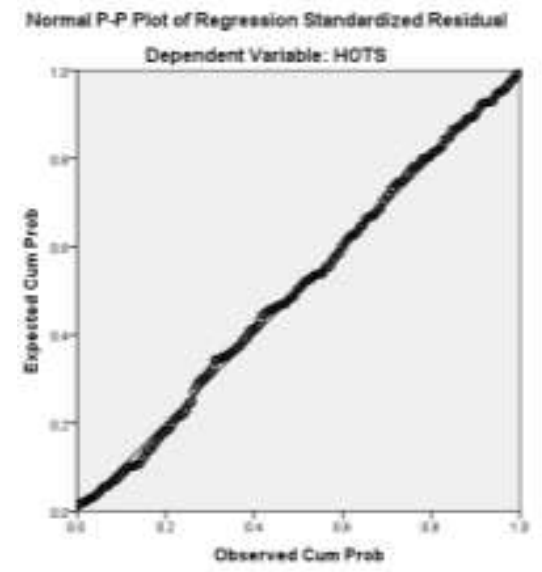

Figure 1. Normal Probability Plot of Regression Standardized Residual Dependent Variable: HOTS

Based on the findings on Figure 1, the plotted points tend to go in a straight line. Therefore, a simple linear regression implementation is performed on the data. This is in line with Gupta (2007) explanation that the data is categorized as normal if the plots in the figure follow the diagonal line and do not deviate far from the generated line. 


\section{Correlation between Learning Strategy and HOTS}

Relationships between two or more predictor variables and criterion variables in two or more data sets are classified as correlations. Correlation analysis is illustrated by the numbers used for the purpose of assessing the strength of linear relationships and measuring the direction between two or more variables. Correlation coefficients are the agents used to measure the existence of relationships level. Correlations between predictor variables (learning strategies) and criterion variables (HOTS) are presented in Table 4.

Table 4. Correlation between Learning Strategies and HOTS

\begin{tabular}{ccc}
\hline & $\begin{array}{c}\text { Learning } \\
\text { Strategie } \\
\end{array}$ & HOTS \\
\hline Learning Strategies & 1 & $.194^{* *}$ \\
Pearson correlation & & \\
\hline Sig. (2-tailed) & & .001 \\
$\mathrm{~N}$ & 314 & 314 \\
\hline
\end{tabular}

** Correlation is Significant at the 0.01 Level (2-tailed)

Based on the table output above, the researchers conclude by referring to two decisionmaking principles in correlation analysis;

a) Based on the Significant Value, Sig. (2 Tailed): Based on Table 4, Significant value, Sig. (2tailed) between Learning Strategies and HOTS was $0.001<0.05$, which means that there was a significant correlation between Learning Strategies and HOTS variables.

b) By Star $\left({ }^{* *}\right)$ SPSS: From the above output it is known that the Pearson Correlation value between the two connected variables has two asterisks $\left({ }^{* *}\right)$, which means that there is a correlation between Learning Strategies and HOTS variables with the significant rate of $1 \%$.

With referring on the interpretation of relationship between the variables using coefficient correlation by Sarwono (2009), the researchers conclude that there is significant relationship between Learning Strategies and HOTS in Accounting Studies even in weak correlation (0.194).

\section{Regression between Learning Strategy and HOTS}

Simple linear regression is used for the purpose of measuring the effect of the independent variable on the dependent variable. Equation that signifies the statistical relationship between one or more explanatory variable and responding variable could be produced through regression analysis. Thus through regression analysis, the development of relationship model between explanatory variable and responding variable could be created. For the purpose of developing a regression equation, two types of coefficients were produced by SPSS 21.0 which is standardized coefficients and unstandardized coefficients as presented in Table 6. 
Vol. 8, No. 4, 2019, E-ISSN: 2226-6348 @ 2019 HRMARS

Table 6. Coefficient of the Estimated Regression Model of HOTS and Learning Strategies

\begin{tabular}{|c|c|c|c|c|c|c|}
\hline \multirow{2}{*}{ Mode } & & \multicolumn{2}{|c|}{$\begin{array}{c}\text { Unstandardized } \\
\text { Coefficients }\end{array}$} & \multicolumn{3}{|c|}{$\begin{array}{c}\text { Standardized } \\
\text { Coefficients }\end{array}$} \\
\hline & & Beta & $\begin{array}{l}\text { Std. } \\
\text { Error }\end{array}$ & Beta & $\mathrm{t}$ & Sig. \\
\hline \multirow[t]{2}{*}{1} & $\begin{array}{l}\text { (Constan } \\
\text { t) }\end{array}$ & 46.442 & 4.862 & & 9.55 & 0.000 \\
\hline & $\begin{array}{c}\text { Learning } \\
\text { Strategie } \\
\mathrm{s}\end{array}$ & 4.349 & 1.243 & 0.194 & 3.49 & 0.001 \\
\hline
\end{tabular}

Measurement in different units towards explanatory variable is one of the reasons standardized coefficients is suitable to be used in multiple regression. Coefficient correlation value is gained through regression analysis after explanatory variable is standardized. However, standardization of explanatory variable does not happen in simple linear regression. Hence, unstandardized coefficient is used to presume regression equation (Best \&Kahn, 1998).

According to Table 6 , the constant value of the unstandardized coefficient is 46,442 . These values suggest that if students do not have a learning strategy in accounting studies, then the average value of HOTS students in Accounting studies is 46.442. Furthermore, the regression coefficient value shown in the analysis was 4.35 . This value explains that with every $1 \%$ increase in learning strategies, then HOT students' mastery in Accounting Studies will increase by 4.35.

In line with Table 6, shortcut value is 46.442 while sloping value is 4.349 for learning strategies. In brief, the relationship between Learning Strategies and HOTS is presented through the following regression equation:

$$
\text { HOTS }=46.442+4.349 \text { Learning Strategies }
$$

Apart from that, the output from the simple linear regression analysis show the magnitude of the Effect between Learning Strategies and HOTS as shown in Table 7.

Based on Table 7, by referring to the value of $\mathrm{R}$ square (0.038) it was explained that the magnitude of the Effect between Learning Strategies and HOTS in Accounting Studies was 3.8\% while $96.2 \%$ of HOTS was influenced by other variables not examined. As a summary, the learning strategy had a positive effect on the HOTS level with the influence's value as $3.8 \%$. These positive influences explain that increasing student learning strategies will have an impact on increasing HOTS students in Accounting Studies. 
Table 7. The Magnitude of the Effect between Learning Strategies and HOTS

\begin{tabular}{ccccc}
$\begin{array}{c}\text { Mode } \\
\text { I }\end{array}$ & $R$ & R Square & $\begin{array}{c}\text { Adjusted } \\
\text { R Square }\end{array}$ & $\begin{array}{c}\text { Std. } \\
\text { Error of } \\
\text { the } \\
\text { Estimate }\end{array}$ \\
\hline 1 & $.194^{a}$ & .038 & .035 & 12.565 \\
\hline
\end{tabular}

Based on Table 7, by referring to the value of $\mathrm{R}$ square (0.038) it was explained that the magnitude of the Effect between Learning Strategies and HOTS in Accounting Studies was 3.8\% while $96.2 \%$ of HOTS was influenced by other variables not examined. As a summary, the learning strategy had a positive effect on the HOTS level with the influence's value as $3.8 \%$. These positive influences explain that increasing student learning strategies will have an impact on increasing HOTS students in Accounting Studies.

\section{Conclusion}

According to the research findings and discussions, the researcher found that there is positive significant relationship between Learning Strategies and HOTS in Accounting Studies. Past researches had even proven the importance of Learning Strategies to produce students that is not only critical and innovative but also proactive. This finding is supported by a study conducted at Universiti Kebangsaan Malaysia (UKM) in Ahmad, Hussin, Azman, and Mohd Jelas (2000) who explained that the practice of learning techniques accounted for $20 \%$ of the variation in student achievement in science and mathematics.

The need to master HOTS among school students and higher education institution has become a re-condition that qualifies them to compete for their positions in higher education institution and world jobs market. Therefore, the researcher suggests that a research linked to HOTS and factors that influence its application is performed by involving more respondent on various subjects as focus so that comparison of research finding could be observed.

\section{Corresponding Author}

Suhaida Abd Kadir (PhD) is a senior lecturer at Faculty of Educational Studies, University Putra Malaysia, 43450, Serdang, Malaysia. Email: suhaida@upm.edu.my

\section{Acknowledgment}

The researchers also like to acknowledge the Ministry of Higher Education (MOHE) and University Putra Malaysia for the financial funding of this paper through "Geran - Putra IPS" UPM (GP-IPS/2018/9608800), for Research University Grant (RUG).

\section{References}

Afsaneh, G. (2017). The Interplay between Reflective Thinking, Critical Thinking, Self-Monitoring, and Academic Achievement in Higher Education. Higher Education, Volume 74, Number 1, Page 101. 
INTERNATIONAL JOURNAL OF ACADEMIC RESEARCH IN PROGRESSIVE EDUCATION AND DEVELOPMENT

Vol. 8, No. 4, 2019, E-ISSN: 2226-6348 @ 2019 HRMARS

Ahmad, A. R., Hussin, M., Azman, N., \& Jelas, M. Z. (2000). Strategi pembelajaran dan Hubungannya dengan Pencapaian Akademik Pelajar-Pelajar Melayu Luar Bandar: Pengaruh modul latihan Pendidikan. Laporan Akhir Penyelidikan Jangka Pendek. Fakulti Pendidikan, UKM.

Anderson, O. W., \& Krathwohl, D. R. (2001). Taxonomy for Learning, Teaching, and Assessing: A Revision of Bloom's Taxonomy of Educational Objectives. A Bridged Edition. New York: Addison Wesley Longman, Inc.

Baskin, S., Iscan, A., Karagoz, B., \& Birol, G. (2017). The Use of Vocabulary Learning Strategies in Teaching Turkish as a Second Language. Journal of Education and Practice, Volume 8, No.9.

Bathuma, S., \& Kalaimakal, P., (2014). The Usage of Language Learning Strategies in Malaysian Private Secondary Schools. Advances in Language and Literary Studies Vol. 5, No.4.

Best, J. W., \& Kahn, J. V. (2007). Research in education. New Delhi: Prentice hall of India.

Carol, A. C., David, R. M., \& Peter, J. I. (2011). Cognitive Strategies and Study Habits: An Analysis of the Measurement of Tertiary Students' Learning. British Journal of Educational Psychology, Volume 61 Issue 3.

Curriculum Development Division (2016). Buku Penerangan Kurikulum Standard Sekolah Menengah (KSSM). Putrajaya: Kementerian Pendidikan Malaysia.

Dansereau, D. F. (1985). Learning Strategy Research. DIm. Segal, J.W., Chipman, S.F. \& Glaser, R. Thinking and Learning Skills 1, 175-180. London: Lawrence Erlbaum Associates Publishers.

Dumford, A. D., Cogswell, C. A., \& Miller, A. L. (2016a). The Who, What, and Where of Learning Strategies. The Journal of Effective Teaching, 16(1), 72-88.

Dumford, A. D., Cogswell, C. A., \& Miller, A. L. (2016b). The Who, What, and Where of Learning Strategies. The Journal of Effective Teaching, 16 (1), 72-88.

Ea, J., Chang, A., \& Tan, O. S. (2005). Thinking About Thinking: What Educators Need to Know. Singapore: National Institute of Education, Nanyang Technological University, McGraw Hill Education.

Hassan, R. (2017). Gaya dan Strategi Pembelajaran Bahasa Melayu dalam Kalangan Pelajar Perancis. Journal of Language Studies, 17(1), 125-146.

Ibrahim, N. (2010). Strategi Pembelajaran dan Sikap Terhadap Komputer bagi Mata Pelajaran Information and Communication Technology Pelajar Tingkatan Empat. Tesis Doktor Falsafah: Universiti Putra Malaysia.

Jamie, L. J., Mark, A. M., Steven, M. W., \& Tyler, A. K. (2014). Teaching to the Test...or Testing to Teach: Exams Requiring Higher Order Thinking Skills Encourage Greater Conceptual Understanding. Educational Psychology Review, Volume 26, Number 2, Page 307.

Jeffrey, W. M. (2014). Higher Order Thinking and Metacognition in the First- year Core-education Classroom: A Case Study in the Use of Color-Coded Drafts. Open Review of Educational Research, 1:1, 56-69.

Kikas, E., \& Jogi, A. L. (2016). Assessment of Learning Strategies: Self-Report Questionnaire or Learning Task. European Journal of Psychology of Education, 31(4), 579-593. https://doi.org/10.1007/s10212-015-0276-3

Lopez, V., Ibanes, O. J., \& Racines, P. O. (2017). Students' Metacognition and Cognitive Style and Their Effect on Cognitive Load and Learning Achievement. Educational Technology \& Society, 20 (3), 145-157.Che Ahmad \& Sanip, 2014 
Mansuri, R. (2002). Hubungan Antara Strategi Pembelajaran dengan Pencapaian Pelajar Tingkatan Empat Dalam Mata Pelajaran Prinsip Akaun di Sekolah Menengah. Tesis Sarjana: Universiti Kebangsaan Malaysia.

Mohamed, S. Z. (2006). Kesan Pendekatan Penyebatian Kemahiran Berfikir Kreatif dalam Pengajaran Karangan Deskriptif dan Karangan Imaginatif dalam Kalangan Pelajar Tingkatan IV. Tesis Doktor Falsafah: Universiti Sains Malaysia.

Onosko, J. J., \& Newmann, F. M. (1994). Creating more thoughtful learning environments, In J.N.Mangieri \& C.C. Block (Eds.). Creating powerful thinking in teachers and students: Diverse perspectives. Fort Worth: Harcourt Brace College Publishers.

Sanip, F. A., \& Ahmad, C. N. (2014). Kesedaran Strategi Metakognitif dan Kemahiran Berfikir Aras Tinggi dalam Kalangan Pelajar Biologi. Jurnal Penyelidikan Pendidikan, 15.

Sanoff, H. (2000). Community Participation Methods in Design and Planning. New York: Wiley. (Che Ahmad \& Sanip, 2014).

Sarwono, J. (2009). Statistik itu Mudah: Panduan Lengkap untuk Belajar Komputasi Statistik menggunakan SPSS 16. Yogyakarta: Penerbit Universitas Atma Jaya.

Weinstein, C. E., \& Mayer, R. E. (1986). The Teaching of Learning Strategies. In M. Wittrock (Ed.), The handbook of Research on Teaching (pp. 315-327). New York: Macmillan.

Weinstein, C. E., Zimmerman, S. A., \& Palmer, D. R. (1988). Assessing Learning Strategies: The Design and Development of the LASSI. In Weinstein, C. E., Goetz, E. T., Alexander, P. A. (Eds.), Learning and Study Strategies: Issues in Assessment, Instruction and Evaluation (pp. 25-40). San Diego, CA: Academic Press.

Wijnen, M., Loyens, S. M. M., Smeets, G., Kroeze, M., \& Van, H. D. M. (2017). Comparing ProblemBased Learning Students to Students in a Lecture-Based Curriculum: Learning Strategies and The Relation With Self-Study Time. European Journal of Psychology of Education, 32(3), 431-447. https://doi.org/10.1007/s10212-016-0296-7

Yee, M. H., Yunos, M. J., Othman, W., Hassan, R., Tee, T. K., \& Mohamad, M. M. (2015). Disparity of Learning Styles and Higher Order Thinking Skills among Technical Students. Procedia Social and Behavioral Sciences, 204, $143-152$. 